OPEN ACCESS

Edited by:

Teodoro Semeraro,

University of Salento, Italy

Reviewed by:

Marzia Vergine,

University of Salento, Italy

Alessio Turco,

University of Salento, Italy

*Correspondence:

Emin Yahya Menteșe

eminmentese@gmail.com

Specialty section:

This article was submitted to

Land Use Dynamics,

a section of the journal

Frontiers in Environmental Science

Received: 07 October 2020

Accepted: 12 February 2021

Published: 14 May 2021

Citation:

Menteşe EY and Tezer A (2021)

Impacts of Infrastructure

Developments on Ecosystem Services

Potential in Istanbul.

Front. Environ. Sci. 9:614752.

doi: 10.3389/fenvs.2021.614752

\section{Impacts of Infrastructure} Developments on Ecosystem Services Potential in Istanbul

\author{
Emin Yahya Menteşe ${ }^{1 \star}$ and Azime Tezer ${ }^{2}$ \\ ${ }^{1}$ Kandilli Observatory and Earthquake Research Institute, Boğaziçi University, Istanbul, Turkey, ${ }^{2}$ Department of Urban and \\ Regional Planning, Istanbul Technical University, Istanbul, Turkey
}

Istanbul has been subject to drastic spatial changes in the last decade due to major investments in the northern section of the city. The primary purpose of the research was to interpret the ecological outcomes of spatial use changes due to such urban development activities and enhance the environmental impact assessment process by adopting an analytical and holistic approach. The approach used in the analysis is based on a model called "matrix model" developed specifically to estimate ecosystem services (ES) capacity of a given area depending on the spatial use types. With the use of this method, one can estimate how spatial use influences ES capacity in positive or negative ways, which ES type is affected most, and which part of the spatial change causes most impact on ecological assets. The methodology is applied for three different investment projects in Istanbul, respectively: North Marmara Motorway (NMM), Istanbul Airport, and Canal Istanbul. While the first two have been mostly completed, the third is in the planning phase. Corine Land Cover datasets for 2012 and 2018 are used as basis datasets within the methodology, and spatial plans of Canal Istanbul are used for future projections. Based on these datasets, ES capacity analysis is carried out for each year for the area of investment, and estimation results are compared. The analysis results indicate that these investments have caused and will cause severe ES losses as expected. The outputs prove that the "matrix model" can be used to evaluate ecological impacts in a straightforward, efficient, and inclusive way for evaluating spatial changes. The authors suggest that environmental impact assessments for such major investments must represent a comprehensive outlook based on more simplistic but yet informative approaches that highlight the potential losses of not only ecological assets but also their functions and benefits. In this context, it is strongly recommended that there is a paradigm shift in the understanding of the "environmental impact" in a direction where environment is not acted upon as a solid, rigid, and stable "land cover" but instead a living organism that produces benefits and services for the whole components of the ecosystem on earth, including humankind.

Keywords: ecosystem services, spatial planning, Istanbul, land use change, Corine land Cover, impact assessment, environmental impact 


\section{INTRODUCTION}

According to the UN, it is projected that the world population will reach 8.9 billion in 2050, increasing by $47 \%$ between 2000 and 2050. It is also estimated that less-developed regions will contribute to more of this increase by growing by $58 \%$ (United Nations, 2004). Moreover, it is known that $52 \%$ of the world population (more than 4 billion) today lives in urban areas, and in 2050, it is projected that the population in urban areas will be around 6.3 billion (UN, 2012). Facing such a big challenge and being as the engines of the economic growth, cities require great sensitivity for investment decisions in various sectors to sustain their viability (European Commission, 2008).

The critical significance of urban ecosystems and biodiversity has been well cited in the literature and global policy documents, especially with the growing concern of climate change impacts. Climate change challenges together with human impacts stimulate urban authorities to improve more ecosensitive and nature-based spatial management solutions in urban settings (Elmqvist et al., 2013; UN, 2015; McPhearson et al., 2018). This is very clearly emphasized with the press release of the UN Secretary General Antonio Guterres as follows:

"We need healthy ecosystems to achieve the Sustainable Development Goals and to address climate change: they can provide $37 \%$ of the mitigation needed to limit global temperature rise", hence, wellbeing of citizens and nature will be achieved only by maintaining the function of urban ecosystems to provide sustainability and resilience of cities (Guterres, 2019).

In order to sustain the well-being and productivity of the cities, there has to be a fixed level of interruption of resources/assets due to human activities that reduce the ability of capacity of the cities to sustain humanity in the future (Arrow et al., 1995). Alberti summarizes this approach by stating that urbanization must consider the limits of natural resources and act not only for the people living within the boundaries today but also for the future generations (Alberti, 1996).

It is known that geographic borders of cities grow in line with the urban population; nevertheless, it is also noted that in the 2000-2015 period, the real growth rate of cities was larger than the population growth rate, which indicates urban sprawl that results due to the refunctioning and consumption of rural lands (UN, 2015). The most significant characteristics of urban sprawl are an increase in transportation distances, depletion of lands, and fragmentation of natural ecosystems that minimize the benefits provided by nature (Kişlalığlu and Berkes, 2010). As a result, due to the dependence of ecological equilibrium on the dimension and spatial use types of the cities (Orishimo, 1982), in order to sustain the environmental health and natural resources, ecological concerns must be considered in determining the spatial use types of the cities, or in other words, ecology-driven spatial planning must be in place (Chen et al., 2014).

In the era of climate change, deciding the proper spatial use type for a given area under specific socioeconomic conditions and adoption of sustainability concerns are critical for reducing the loss of biodiversity, natural habitats, land degradation, guaranteeing the sustainable use of resources, and increasing resilience of ecosystems. Thereof, the success of sustainable land use and management practices is decisive to ensure sustainability/ resilience or mitigate degradation/vulnerability of land resources (FAO, 2018). Consequently, demand on natural resources increases in correlation with urban population/development, and therefore, the most critical concern in the urbanization process is to manage resource requirement (Vega-Azamar et al., 2015).

In general, a spatial planning process follows the steps of data acquisition (environmental, geological, socioeconomic, demographic, and physical), analysis of data, synthesis of the analyses in line with plan vision, and determination of spatial use types. Nevertheless, ecological datasets are mostly treated as a land cover instead of a living ecosystem, which neglects the real importance and value of ecosystems and leads to overuse and extinction of ecological resources (Menteșe et al., 2020). In this regard, maintaining the services and benefits provided by ecosystems in the optimum level is the fundamental component of ecological sustainability (Millennium Ecosystem Assessment, 2005). Therefore, understanding the spatial impacts of the development/investment processes is of great importance in spatial planning in order to manage and reduce possible losses in ecosystems due to spatial use changes (Kopperoinen et al., 2014).

Istanbul as the largest city in Europe and Turkey has been subject to significant urban expansion in the last decades, where its population has grown from 10 million in 2000 to 16 million in 2020 (Turkish Statistic Institute). Even though the expansion has mostly occurred in the east-west direction, recent investments in last 8 years have shifted the pressure to the northern parts where the ecological resources of the city are accommodated. Istanbul lays on two continents (Thrace Peninsula/Europe and Kocaeli Peninsula/Asia), which are part of the Pan-European Ecological Network (PEEN) in southeastern Europe with its coastal dunes and forest/heathland habitats taking place on the northern parts of the city (Biro et al., 2006; Tezer, 2020).

The first investment in the last 8 years has been the construction of North Marmara Motorway (NMM), which was started to be built in 2013. Construction of the highway is still continuing, and when finished with all linking roads, the total length of the highway will reach almost $400 \mathrm{~km}$, including a bridge pass over Bosphorus (Url-1). After the completion of main highway parts that take place in the center section around Bosphorus, the second investment was started, namely, Istanbul Airport. Construction of the Istanbul Airport started in 2014, and the first phase of the project was concluded in 2019, covering $1,440,000 \mathrm{~m}^{2}$ indoor area. Once fully completed by 2025 , the airport will combine a total indoor area of $3,200,000 \mathrm{~m}^{2}$ (Url-2).

These investments have shaped and continues to shape Istanbul's landscape drastically in a very short period of time. The areas that are subject to the construction of these engineering investments are invaluable by means of their ecological values. Due to the ecosystem, biodiversity, and environmental assets in those areas that were/are under threat, there were severe discussions in public after the announcement of each project. Nevertheless, the first two of the projects have almost been completed, while one of them is ongoing, although there is 
solid scientific evidence that highlights the harms that can arise due to constructions.

It is certain that these investments are a threat to the ecosystem and its assets over the area they are built upon. Thereof, integrating ecosystem services into such projects in the planning period is of great importance so that the impacts on ecosystems can be regarded beforehand and hence the adverse effects can be reduced to minimum (Millennium Ecosystem Assessment, 2005; Genelleti, 2013).

Since the year 2005, with the release of the Millennium Ecosystem Assessment Report, the "ecosystem services" concept has replaced as an increasingly important paradigm on the agenda of global and national institutions for ensuring the resilience of environment and society being under the risks of ecosystem degradation, biodiversity loss, and climate change, which are the result especially of rampant urbanization and land cover change (Millennium Ecosystem Assessment, 2005; TEEB 2009; Haase et al., 2010). The term ecosystem services, which was used for the first time in the literature in 1981 by Ehrlich and Ehrlich, is based on the concept of nature's services by Westman (1977), or ecosystem functions and the relation with biodiversity by Mooney and Ehrlich in 1997 which is linked with Marsh's book of "Man and Nature," and also is based on the Land Ethic concept of Aldo Leopold. Four of the definitions related to the ES are considered to be among the most widely accepted ones (Albayrak, 2012).

The Millennium Ecosystem Assessment (Millennium Ecosystem Assessment, 2005), as well as many other studies that followed, highlighted the importance of integrating the ES concept into strategic decision-making so that the impacts of development practices on ecosystems and on their benefits and functions can be taken into account at the beginning phase of planning (Genelleti, 2013). In this context, ES mapping emerges as an invaluable tool since ES maps bring the ES concept into implementation and decisionmaking level where maps can represent complex spatial information in a visual and tangible way (Burkhard et al., 2014). ES maps are also beneficial for raising awareness about how ecosystems can provide goods, regulate nature, give information about ecosystem interaction, and enhance environmental quality (Jacobs et al., 2015). Moreover, maps can be used as decision support tools in spatial development under the conditions that ES maps are based on accurate, precise, and concrete data (Müller et al., 2016; Tezer et al., 2020).

Within this context, this research focuses on the impacts of NMM projects on ES capacity in the northern part of Istanbul. The analysis is based on spatial use change between 2012 (when none of the investments were at place) and 2018 (when the construction was mostly completed). In estimations, Corine Land Cover (CLC) datasets are used, and the calculations aim at understanding and interpreting how such investments can affect ecosystems and showing how the ES concept can help enhance conventional environmental impact analysis approaches.

\section{STUDY AREA: NORTH MARMARA MOTORWAY (NMM), ISTANBUL AIRPORT, AND CANAL ISTANBUL}

NMM will have a total distance of $400 \mathrm{~km}$ including the connecting roads when completed: in total, 14 viaducts, 37 bridges, 3 tunnels,
19 overpasses, 43 underpasses, and 118 culverts in the European part of the NMM; and in the Asian part, a total of 16 viaducts, 106 bridges, 5 tunnels, 54 overpasses, 53 underpasses, and 481 culverts are built. With the completion of the project, it is aimed to increase service quality and safety in transportation by separating regional traffic which grows and develops around the main transportation arteries in the East-West direction in the northern Marmara region created by urbanization and industrialization and intercity and international traffic passing through.

Located on the European side of Istanbul, by the Black Sea shore, the new airport is situated at the junction of Çatalca-Göktürk-Arnavutköy, between the Tayakadın and Akpınar villages. Covering an area of 76.5 million square meters, Istanbul airport serves as a global transportation hub between Asia, Africa, and Europe.

Canal Istanbul is a controversial project that has been subject to many discussions in recent years. The main aim of the canal construction has been announced as minimizing the negative effects of ship transportation on the Bosphorus Strait in the environmental impact assessment (EIA) report of Canal Istanbul (2019). In the EIA report, it is stated that the number of ships passing from the Bosphorus Strait in one year can reach up to 86,000 by 2070 , which must be reduced in order to sustain the ecological, social, and cultural assets of the Çinar Mühendislik Müşavirlik A.Ş. (2017).

The proposed canal route crosses Istanbul from the Black Sea to Marmara Sea, dividing the city into three pieces and creating an island part in the middle (Figure 1). The total length of the canal is estimated to reach around $45 \mathrm{~km}$ with a width of at least 275 and depth of $20.75 \mathrm{~m}$. Construction of the strait is estimated to conclude in 7 years and provide service for at least 100 years (Cinar Mühendislik Müşavirlik A.Ș. (2017)).

Within the project, in addition to the strait, specific sections are planned to be built such as emergency docks, command centers, logistical centers, a marina, bridges, and shore facilities. The proposed route is generally surrounded by agricultural zones, partially forests and residential and water bodies. Along these water bodies, Sazlidere Dam, which has the capacity to provide water for Istanbul inhabitants for 24-25 days, is the most important one that has to be canceled if the canal is built (ibid). Approximate locations of the projects are given in Figure 1.

\section{MATERIALS AND METHODS}

In this context, the developed methodology benefits from the ES mapping approach and aims to evaluate the impacts of NMM, Istanbul Airport, and Canal Istanbul on ecosystem services within their impact zones. The analysis is based on before-after comparison regarding the construction times of the investments. For ES mapping, the matrix model developed by Burkhard et al. (2009) is adopted. The matrix model basically depends on assigning scores for the ES potential of each spatial use type. A figure adopted by Burkhard et al. (2009) and Jacobs et al. (2015) is given in Figure 2.

In the matrix as shown in Figure 2, " $\mathrm{SU}_{\mathrm{n}}$ " corresponds to a "spatial use type" and $\mathrm{ES}_{\mathrm{n}}$ corresponds to an ES type such as water 


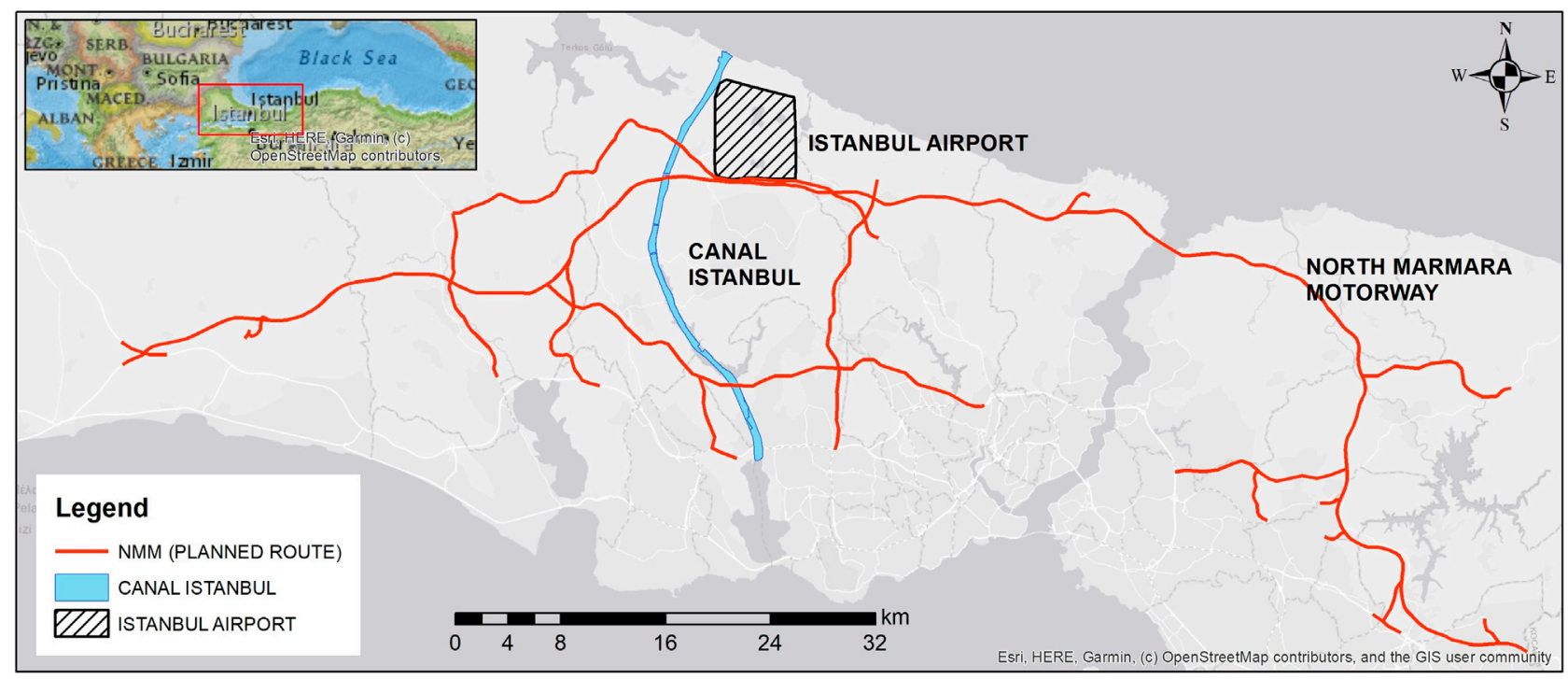

FIGURE 1 | Approximate locations of the projects.

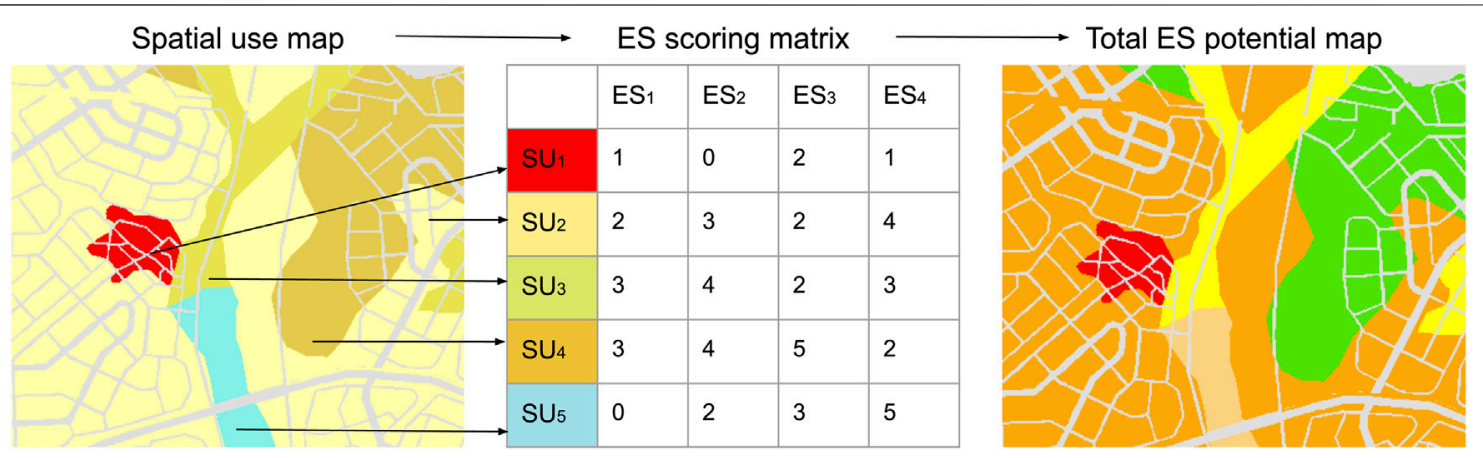

FIGURE 2 | Matrix model concept. (Adopted by Burkhard et al. (2009) and Jacobs et al. (2015)).

regulation, air regulation, and $\mathrm{CO}_{2}$ uptake that this spatial use type provides. As a result of the matrix, total ES potential is calculated by adding up each ES type for each spatial use type. Then the summation is multiplied with the areal quantity of that spatial use type since ES capacity increases in line with the areal quantity of the relevant spatial use type. For each spatial use type, the total ES potential is calculated as in Eq. 1. In the equation, $\Sigma \mathrm{ESp}_{\mathrm{SUT1}}$ corresponds to the ES potential of spatial use type 1, ES1 corresponds to ES capacity score of ES type 1, and AreasuT1 corresponds to areal quantity of spatial use type 1 .

$$
\sum_{E S P} \mathrm{SUT}_{1}=(E S 1+E S 2+E S 3+E S 4+\cdots+E S n) \times \text { AreaSUT }_{1} .
$$

After the total ES capacity for the spatial use types are calculated, their summation results are calculated as the total ES potential for the whole area (Eq. 2). In Eq. 2, $\Sigma E S c$ corresponds to the total ES capacity value for the study area.

$$
\sum \mathrm{ESc}=\sum_{E S p} \mathrm{SUT} 1+\sum_{E S p} \mathrm{SUT} 2+\sum_{E S p} \mathrm{SUT} 2+\ldots+\sum_{E S p} \mathrm{SUTn} .
$$

In the implementation of the methodology, Corine Land Cover (CLC) dataset (https://land.copernicus.eu/pan-european/corine-landcover), which is commonly used for ES mapping, is used as the base data (Burkhard et al., 2009; Jacobs et al., 2015; Müller et al., 2016). Another advantage of using the CLC dataset is the acknowledged standards of the dataset that reduce the risk of data accuracy and precision. In the NMM and Istanbul Airport impact analyses, 2012 and 2018 CLC datasets are used for before-after comparison, and for Canal Istanbul's future impact analysis; 2018 CLC dataset is compared with the proposed spatial plan of the Canal Istanbul project since the implementation of the canal has not started yet. ES scorings are gathered from a previous study carried out by the Istanbul Metropolitan Municipality where, for each spatial use type, an ES capacity score was produced to evaluate overall ES capacity in Istanbul (Istanbul Metropolitan Municipality, 2017). The ES scoring table is given as appendix (Supplementary Appendix A1). 


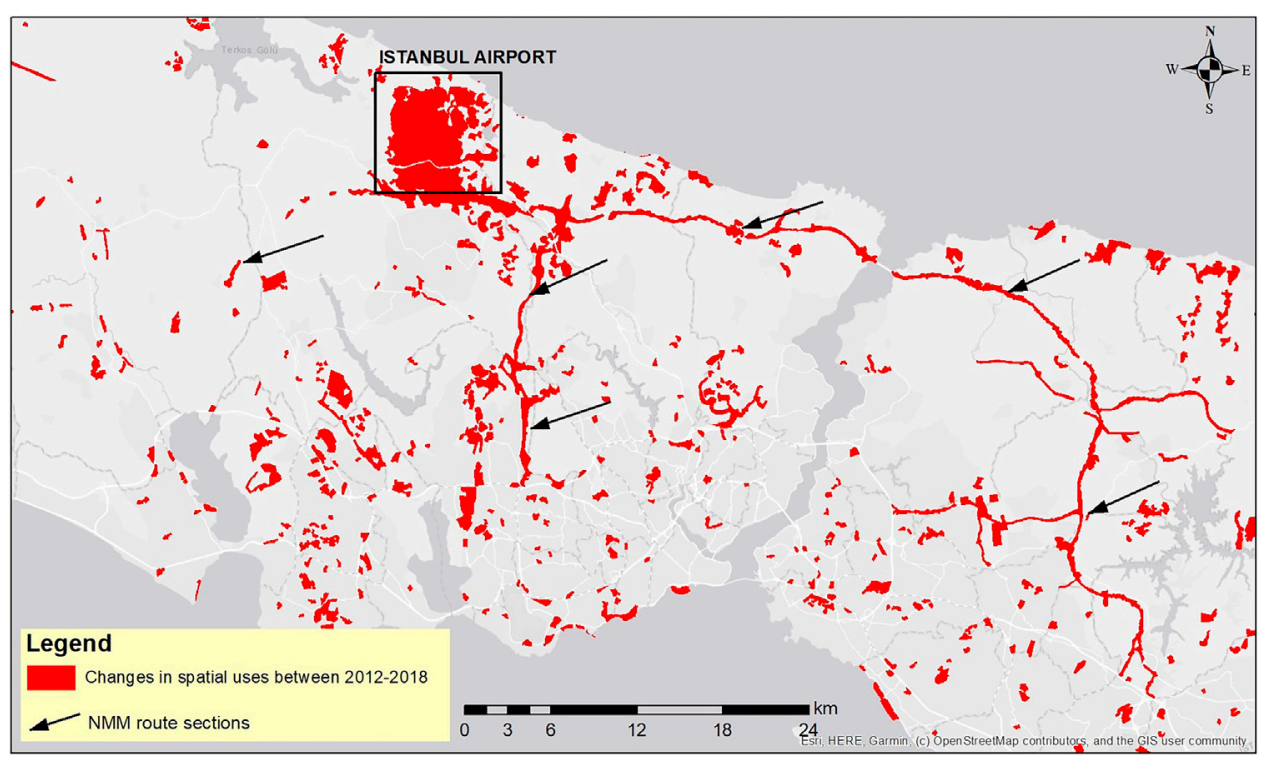

FIGURE 3 | Changes in spatial uses in 2012-2018 period.

It is seen in Supplementary Appendix A1 that forests are accounted as the most valuable ecosystems among others by means of providing ES supply. In all three categories of ES (regulating, cultural, and provisioning), forests are considered way more important than others. It must be noted that forests in Istanbul are an integral part of the urban form and their services are highly benefited by the inhabitants of Istanbul. Istanbul forests are known to provide vital benefits such as mediation of air quality that provides clean air to southern urban zones, pest control that provides natural protection for the agricultural zones around the forests, timber production, and recreational activities (Güneralp et al., 2013; Avc1, 2014). Thereof, loss of forests has much more meaning than spatial changes in Istanbul.

The methodology applied in this research is adopted to provide a more holistic outlook to ecological impacts influenced by the three major infrastructure investments. Although there are EIA reports for each project, the methodology applied here can add supplementary benefit to the understanding of such investments' overall impacts, which is critical to enhance the implementation process and reduce the risks against ecosystem.

In order to implement the methodology, first the dataset that covers whole Europe was clipped to Istanbul boundaries using ArcGIS software (Figure 3). After the clipping operation, zones where NMM and Istanbul Airport are constructed are cropped from the dataset as the analysis dataset. The attributes and values of the dataset are then transferred to tabular format and calculations were carried out.

\section{RESULTS}

\section{Change of ES Potential due to North Marmara Motorway and Istanbul Airport}

As stated in the Methodology section, NMM and Istanbul Airport analyses were carried out based on CLC 2012 and 2018 datasets. It is widely known that CLC datasets are efficient and provide enough accuracy in studies within larger regions (larger than 5 ha) that do not require small-scale details, particularly in ecological studies that cover a wide range of area (Burkhard et al., 2009; European Environment Agency (EEA), 2017). Among CLC-related datasets provided by the European Environment Agency's Copernicus Programme, a processed dataset is also served, namely, "Corine Land Cover Change", and it is renewed periodically compatible with the CLC datasets. In order to maintain the integrity and standardization of the methodology, 2012-2018 land use change dataset has been used as basis data to evaluate the ES impact of NMM and Istanbul Airport in this research. The main logic behind selecting this dataset is to have a reference point for 2012 (when constructions have not started yet) and a comparison point for 2018 (when constructions were almost completed). The significant attributes for this research provided within the dataset are the spatial use type in 2012 and its renewed (changed) type for 2018 with the areal quantity. So, the dataset includes the type of spatial uses that have changed to another one in the 2012-2018 period.

Based on the GIS dataset, it is estimated that 22.387.20 ha of area has been converted from one spatial use type to another in the whole Istanbul metropolitan area. It is clearly observed that NMM and Istanbul Airport constructions have caused a significant level of spatial change in the period of 2012 and 2018. NMM construction caused spatial change in an area of 4.700.52 ha, and 4.016.56 ha were converted due to Istanbul Airport construction. In other words, solely NMM and Istanbul Airport caused the $39 \%$ of spatial change that occurred in the 2012-2018 period (Figure 4).

When assessed in detail, it was observed that NMM and Istanbul Airport are constructed on areas where invaluable natural assets were in place in 2012. Almost 90\% of constructions took place on natural habitats such as broad-leaved 


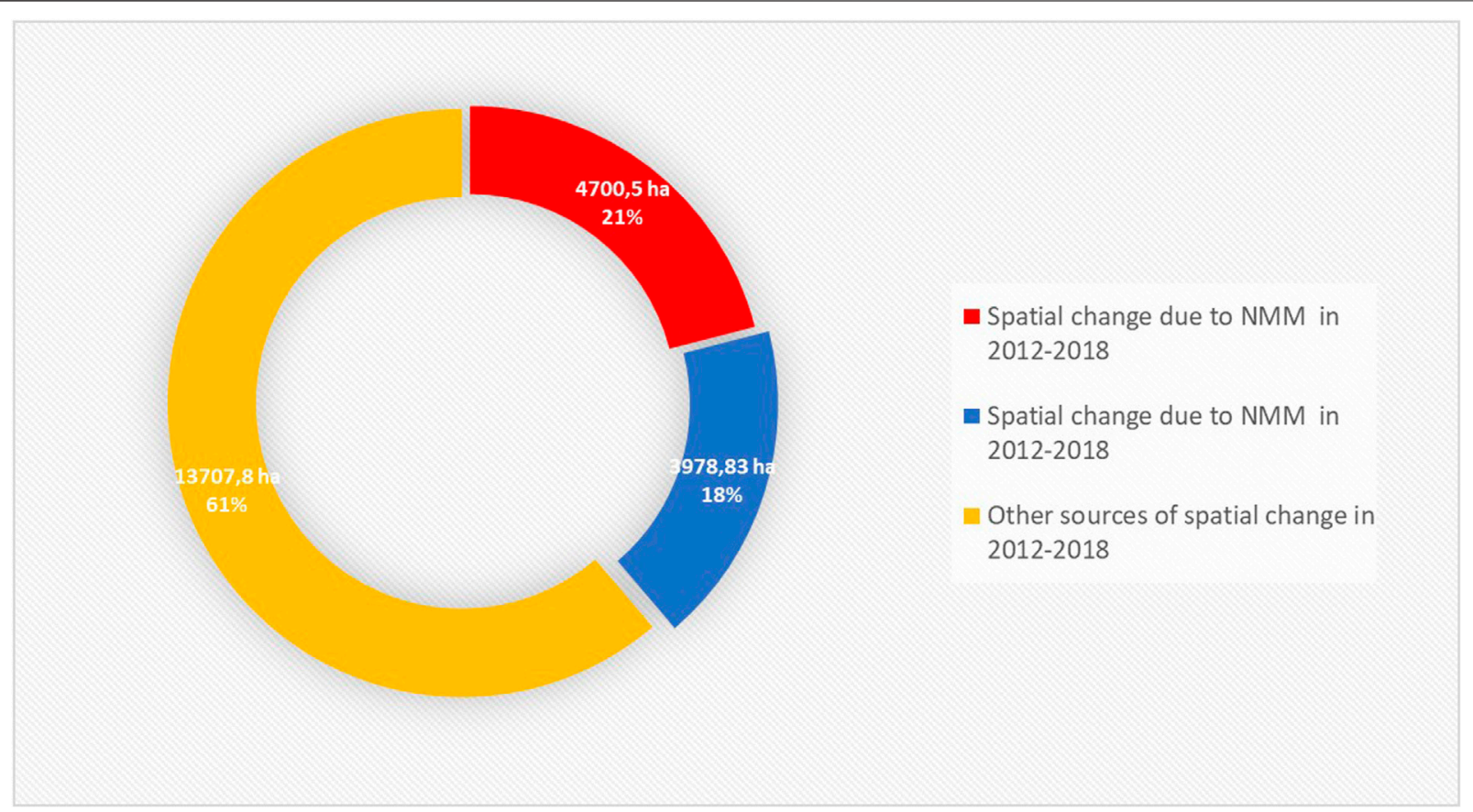

FIGURE 4 | Spatial change ratios between 2012-2018 period and sources of change.

forests, mixed forests, transitional woodland shrubs, pastures, coniferous forest, and natural grasslands. In total, construction of these infrastructures caused approximately 8700 ha of natural habitat loss, that is, NMM caused 4700 ha and Istanbul Airport caused 4000 ha of loss. It is estimated that among other spatial uses, forests are the most effected ones by far. The analysis showed that almost 4720 ha of forests have been lost between 2012 and 2018 . Transitional woodland shrubs, natural grasslands, pastures, and sparsely vegetated areas come second with around 2570 ha of loss (Figure 5).

The conversion of spatial use types in the 2012-2018 period has almost completely been from natural to artificial types. By the year 2018, the area that NMM and Istanbul Airport cover has been shifted to artificial surfaces such as construction sites, industrial or commercial units, mineral extraction sites, and road, rail networks, and associated land. The largest change of spatial use has been "construction" in 2018 within the NMM and Istanbul Airport implementation area which seems related to the ongoing operations of the infrastructure construction process. Only a small portion of area is changed as transitional woodland shrub, natural grassland, and sparsely vegetated areas that extend to an area of 70 ha. A summary of the spatial changes is given in Figure 5, and a detailed analysis table is given in Supplementary Appendix A2 which includes the exchange between each spatial use type between 2012 and 2018 .

The spatial change found in this research due to NMM is compatible with the findings highlighted in the environmental impact assessment reports (AECOM, 2013; Encon, 2018) in which potential losses are explained. In the reports, it is certainly stated that the construction and use of NMM have significant potential of causing losses in natural habitats such as forests, pastures, meadows, water bodies, and water courses. In the reports, it is stated that forests that are supposed to be affected by NMM are productive by $80 \%$ on the Anatolian side and $90 \%$ on the European side (Encon, 2018). Nevertheless, in the environmental impact assessment report that covers the $3^{\text {rd }}$ bridge passing over the Bosphorus Strait (Yavuz Sultan Selim Bridge) and connected motorways (AECOM, 2013), there is a lack of data on forests (and other spatial use types as well) which disables making interpretation about the habitat loss. The analysis results show that Istanbul Airport has also been mainly established on forest areas. Around 4000 ha of the area was constructed in 2012-2018, of which 2078 ha were forests. Assuming that Istanbul Airport's construction process is still ongoing and the airport will be built on 7650 ha of land where the total forest area covers 6172 ha (Tolunay, 2015), loss of forests is subject to continue in the near future.

As stated in the Methodology section, the study is based on a matrix model that enables evaluation of the ES potential for spatial use types. Therefore, the main component of the matrix model is the ES scorings that are assigned for each spatial use type. The scoring matrix given in Supplementary Appendix A1 is constructed based on a workshop carried out with a group of researchers, decision makers, practitioners, and experts in the fields of urban planning, ecology, and environmental engineering (Istanbul Metropolitan Municipality, 2017). In the workshop, 75 experts were asked to evaluate Istanbul's spatial use taxonomy (compatible with CLC) in line with ES classification frames and give ES potential scores out of $0-5$ for each spatial use, in which 0 corresponds to "no potential" and " 5 " to "highest potential." In 


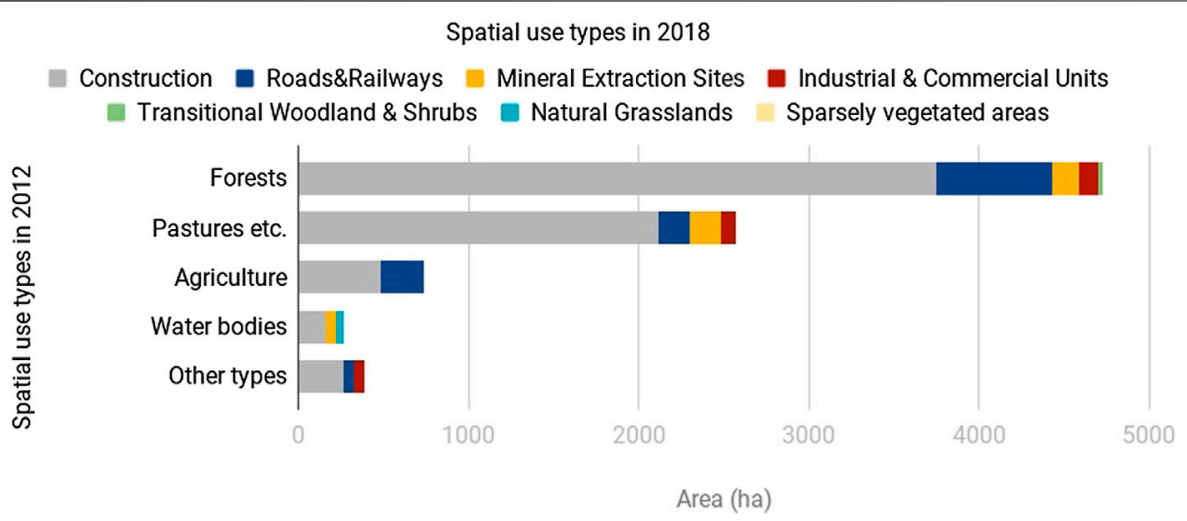

FIGURE 5 | Trade offs between spatial use types in 2012-2018 period.

addition to their expert reviews, observational data from the field surveys were also used to enhance the scorings.

In order to evaluate the amount of ES potential loss for the first case, CLC change dataset was analyzed in tabular format. By multiplying total ES scores (Supplementary Appendix A1) for each spatial use type given for 2012 and 2018 (Supplementary Appendix A2), total ES potential is calculated for both years. As almost all spatial change has been from natural to artificial type of uses, the change in ES potential between 2012 and 2018 datasets is calculated for the implementation zones of NMM and Istanbul Airport. According to the results, the total ES potential provided by 2012 spatial uses sums up to 608.629 .90 , while the 2018 spatial uses produce 3.796 .08 total ES capacity score (Table 1). In Supplementary Appendix A3, a more detailed table is given for interpretation of potential ES change.

It must also be noted that the 2018 CLC dataset does not represent the $100 \%$ completed versions of these investments. Thereof, the analysis results represent the spatial change and ES potential loss partially. Hence, in the near future, it can be assumed that ecological degradation is subject to increase in line with the completion of the NMM project and expansion of Istanbul Airport.

On the ES provision side, it has been estimated the biggest loss of the ES categories area happened to be in "regulating services" since forests are quite efficient with their regulating properties and since they are the largest group by means of the areal quantity that has been lost. In this context, decreases in "mediation of gaseous/air flows," "atmospheric composition and climate regulation," "mediation of liquid flows," "soil formation and composition," "pest and disease control," "natural hazard control," "pollination," and "mediation of waste, toxins and other nuisances by

TABLE 1 | ES potential changes in 2012-2018 due to NMM and Istanbul Airport construction.

Total ES potential

2012 CLC dataset

608.629 .74

2018 CLC dataset

3.796 .08

ES potential loss ecosystems" services can be expected. To know the changes in these services is of great importance to enable decision makers to take action against the risk of losing them.

\section{Potential ES Change due to North Marmara Motorway in Near Future}

As stated earlier, NMM has caused spatial change on an area of 4.700 ha. Nevertheless, the literature suggests that the impact of transportation investments reaches beyond their implementation area and influences a larger ground around their routes (Forman and Alexander, 1998; Bennet et al., 2011). Moreover the impact of transportation networks on biodiversity and ecosystem services is also studied and proved in detail (Strasburg, 2006; Balkenol and Watts, 2009; Barthelmess and Brooks, 2010; Cain et al., 2003).

In that sense, environmental impact reports of NMM segments are prepared for a defined buffer zone along the transportation network. Nevertheless, there are three different EIA reports for NMM which were done for Asian side sections, European side sections, and the Yavuz Sultan Selim Bridge passing section, but while the European and Asian side sections were done for a 400-m buffer zone (Encon, 2018), the report for the bridge passing section was carried out for a 1,000-m buffer zone (AECOM, 2013). Moreover, all of the reports were carried out based on CLC 2006 data, which were not valid back then. Therefore, since the reports do not follow a standard evaluation method and they were carried out separately, it is difficult to gather a holistic point of view with respect to their total impact on the ecosystem.

In this regard, a standard impact area is defined and recalculated within this research based on a $800-\mathrm{m}$ buffer zone (a value close to the average of EIA reports) along the route, in order to estimate potential spatial changes that can occur due to NMM. For the analysis, 2012 CLC data were used since the construction started in 2012. The estimated total impact zone covers an area of 27.773 ha. It is notable that only $11 \%$ of the impact zone is related to urbanized uses such as "discontinuous urban fabric," "continuous urban fabric," "industrial or commercial units," "road and rail networks and associated land," and "mineral extraction sites." Consequently, it was 
TABLE 2 | Distribution of spatial use types within the impact zone in 2012 and 2018.

\begin{tabular}{|c|c|c|c|c|}
\hline Spatial use & Area in 2012 (ha) & Ratio (\%) & Area in 2018 (ha) & Ratio (\%) \\
\hline Nonirrigated arable land & 9251.27 & 33.31 & 8951.11 & 32.23 \\
\hline Broad-leaved forest & 6246.25 & 22.49 & 4530.54 & 16.31 \\
\hline Construction sites & 216.23 & 0.78 & 3414.59 & 12.29 \\
\hline Road and rail networks and associated land & 503.00 & 1.81 & 1658.00 & 5.97 \\
\hline Complex cultivation patterns & 1572.45 & 5.66 & 1371.81 & 4.94 \\
\hline Mixed forest & 1801.66 & 6.49 & 1252.77 & 4.51 \\
\hline Land principally occupied by agriculture, with significant areas of natural vegetation & 1220.38 & 4.39 & 1228.24 & 4.42 \\
\hline Discontinuous urban fabric & 979.47 & 3.53 & 1053.62 & 3.79 \\
\hline Transitional woodland shrub & 1335.42 & 4.81 & 837.99 & 3.02 \\
\hline Industrial or commercial units & 711.90 & 2.56 & 733.31 & 2.64 \\
\hline Pastures & 1149.42 & 4.14 & 727.91 & 2.62 \\
\hline Coniferous forest & 1033.21 & 3.72 & 584.19 & 2.10 \\
\hline Mineral extraction sites & 365.51 & 1.32 & 379.42 & 1.37 \\
\hline Continuous urban fabric & 303.38 & 1.09 & 320.48 & 1.15 \\
\hline Natural grasslands & 584.77 & 2.11 & 300.45 & 1.08 \\
\hline Green urban areas & 132.12 & 0.48 & 126.45 & 0.46 \\
\hline Sea and ocean & 131.21 & 0.47 & 113.18 & 0.41 \\
\hline Permanently irrigated land & 74.26 & 0.27 & 74.26 & 0.27 \\
\hline Sport and leisure facilities & 55.35 & 0.20 & 55.35 & 0.20 \\
\hline Water bodies & 72.07 & 0.26 & 35.83 & 0.13 \\
\hline Dump sites & 34.15 & 0.12 & 24.02 & 0.09 \\
\hline Sparsely vegetated areas & 0.00 & 0.00 & 0.00 & 0.00 \\
\hline
\end{tabular}

determined that forests, agricultural areas, and natural habitat are the most affected sites within the impact zone.

Broad-leaved, coniferous, and mixed forests combine for $33 \%$ of the whole impact zone, while agricultural areas sum up to $44 \%$ of the whole impact zone of the NMM. The rest of the areas under the impact zone is associated with natural habitats too, such as "natural grasslands" and "pastures" (Table 2). Considering the previous experiences in Istanbul where two bridges were constructed over the Bosphorus Strait along with the connecting highways, it is predicted that all of the agricultural assets and natural resources within this impact zone are under threat.

In order to evaluate the future changes due to NMM investment, comparing the 2012 and 2018 CLC datasets gives meaningful results. It was found out that the impact of NMM construction is beyond its construction limits. Although the major part of the spatial change has emerged as a shift to transport infrastructure and construction sites, there are some minor signs of urbanization. It is seen that there are some increases in discontinuous and continuous urban fabric in the impact zone that reach 90 ha of area in total. It is not easy to relate this change to NMM construction, but similar to analysis results given in Figure 5, the biggest loss has been in forests and agricultural lands in the potential impact zone of NMM.

In order to interpret possible changes in ES potential based on NMM, first the difference between the years 2012 and 2018 was analyzed. First, a "clip" operation was done in ArcGIS between the CLC 2012 and NMM impact zone, and then the same analysis was carried out with CLC 2018. The difference between 2012 and 2018 datasets for the same region proves that the biggest loss has been due to the loss of broad-leaved forests that are mostly composed of oak trees. In addition to broad-leaved forests, mixed type and coniferous forests are the second and third most impacted spatial use types, respectively (Table 3 ).
In order to understand and build actions to reduce ecological loss in near future due to NMM construction, emphasis must be put on CLC 2018 analysis results. Based on spatial use change analysis within a $400-\mathrm{m}$ buffer zone, over an impact area of approximately $27.780 \mathrm{ha}$, it is analyzed that at least 1.312.392.12 units (ES Score $\mathrm{x}$ Area) of ES potential must be protected to sustain the environmental quality in the area. Otherwise, it can be claimed that an almost quadruple amount of the loss that occurred in 2012-2018 is likely to occur in the near future.

EIA reports express that NMM has the potential to increase noise levels, decrease air and water quality, pollute soil, and cause degradation of ES in its whereabouts (AECOM, 2013; Encon, 2018). ES potential analyses are in line with the EIA reports of the NMM construction. In the EIA report for the bridge section and connecting highways of the NMM (AECOM, 2013), there are references to other scientific reports that estimate the possible forest losses may reach unsustainable levels if proper planning and development actions are not taken (Ayazli et al., 2010).

\section{Change of ES Potential due to Canal Istanbul}

Canal Istanbul is one of the most controversial projects that came into the agenda of Turkey in the last decade. The proposed canal route is around $45 \mathrm{~km}$ long with a width of at least $275 \mathrm{~m}$ and depth of $20.75 \mathrm{~m}$. Although the construction of the strait is estimated to conclude in 7 years, spatial plans of the canal have already been published by the Ministry of Environment and Urbanization. In this regard, in line with the scope of this research, we focused on the spatial plans of the canal, in order to estimate how the canal can affect the ecosystem in the region within the near future. 
TABLE 3 | ES potential change between 2012 and 2018 in the NMM impact zone.

\begin{tabular}{|c|c|c|c|c|c|}
\hline Spatial use & Areal change & ES score & $\begin{array}{c}\text { ES potential } \\
2012\end{array}$ & $\begin{array}{c}\text { ES potential } \\
2018\end{array}$ & $\begin{array}{c}\text { ES potential } \\
\text { change }\end{array}$ \\
\hline Broad-leaved forest & -1715.72 & 87 & $543,424,09$ & $394,156,60$ & $-149267,49$ \\
\hline Mixed forest & -548.89 & 89 & $160,348,00$ & $111,496,48$ & $-48851,52$ \\
\hline Coniferous forest & -449.02 & 87 & 89889,37 & 50824,31 & $-39065,07$ \\
\hline Transitional woodland shrub & -497.43 & 60 & 80125,47 & 50279,50 & $-29845,96$ \\
\hline Pastures & -421.50 & 51 & 58620,19 & 37123,49 & $-21496,70$ \\
\hline Nonirrigated arable land & -300.15 & 54 & $499,568,36$ & $483,360,14$ & $-16208,22$ \\
\hline Natural grasslands & -284.32 & 51 & 29823,32 & 15322,85 & $-14500,48$ \\
\hline Complex cultivation patterns & -200.64 & 44 & 69187,98 & 60359,72 & -8828.26 \\
\hline Water bodies & -36.24 & 69 & 4972.87 & 2472.09 & -2500.78 \\
\hline Sea and ocean & -18.02 & 66 & 8659.68 & 7470.12 & -1189.56 \\
\hline Green urban areas & -5.67 & 23 & 3038.68 & 2908.36 & -130.31 \\
\hline Sparsely vegetated areas & 0.00 & 22 & 0.00 & 0.00 & 0.00 \\
\hline Construction sites & 3198.36 & 0 & 0.00 & 0.00 & 0.00 \\
\hline Road and rail networks and associated land & 1155.00 & 0 & 0.00 & 0.00 & 0.00 \\
\hline Industrial or commercial units & 21.40 & 0 & 0.00 & 0.00 & 0.00 \\
\hline Mineral extraction sites & 13.90 & 0 & 0.00 & 0.00 & 0.00 \\
\hline Dump sites & -10.14 & 0 & 0.00 & 0.00 & 0.00 \\
\hline Sport and leisure facilities & 0.00 & 15 & 830.23 & 830.23 & 0.00 \\
\hline Permanently irrigated land & 0.00 & 44 & 3267.33 & 3267.33 & 0.00 \\
\hline Continuous urban fabric & 17.09 & 22 & 6674.43 & 7050.46 & 376.03 \\
\hline Land principally occupied by agriculture, with significant areas of natural vegetation & 7.86 & 49 & 59798,75 & 60183,67 & 384.92 \\
\hline \multirow[t]{2}{*}{ Discontinuous urban fabric } & 74.15 & 24 & 23507,21 & 25286,76 & 1779.55 \\
\hline & Total & 1.641 .735 .96 & 1.312 .392 .12 & -329.343 .84 & \\
\hline
\end{tabular}

TABLE 4 | Spatial uses in the plan area in 2012 and 2018.

\section{Spatial use}

Nonirrigated arable land

Land principally occupied by agriculture, with significant areas of natural vegetation

Water bodies

Pastures

Complex cultivation patterns

Discontinuous urban fabric

Transitional woodland shrub

Broad-leaved forest

Mineral extraction sites

Mixed forest

Natural grasslands

Construction sites

Beaches, dunes, sands

Coniferous forest

Industrial or commercial units

\begin{tabular}{cccc} 
Area in 2012 (ha) & Ratio (\%) & Area in 2018 (ha) & Ratio (\%) \\
\hline 6.704 .93 & 60.28 & 6.706 .50 & 60.29 \\
1.542 .85 & 13.87 & 1.550 .75 & 13.94 \\
772.98 & 6.95 & 772.98 & 6.95 \\
779.39 & 7.01 & 770.73 & 6.93 \\
547.34 & 4.92 & 547.34 & 4.92 \\
344.53 & 3.10 & 344.53 & 3.10 \\
180.29 & 1.62 & 171.54 & 1.54 \\
138.15 & 1.24 & 127.49 & 1.15 \\
43.74 & 0.39 & 52.40 & 0.47 \\
41.56 & 0.37 & 29.04 & 0.26 \\
17.21 & 0.15 & 26.06 & 0.23 \\
0.42 & 0.00 & 13.63 & 0.12 \\
4.94 & 0.04 & 4.94 & 0.04 \\
4.20 & 0.04 & 4.20 & 0.04 \\
0.95 & 0.01 & 1.37 & 0.01 \\
\hline
\end{tabular}

The spatial plans of the Canal Istanbul cover approximately 11.200 ha of area. According to the CLC dataset for the year 2018, the area that Canal Istanbul's plan covers mostly consists of agricultural areas. Almost $78 \%$ of the whole area is formed by "nonirrigated arable land," "land principally occupied by agriculture, with significant areas of natural vegetation," and "complex cultivation patterns." In addition to agricultural assets, around $18 \%$ of the plan area includes natural habitats such as pastures, water bodies, forests, grasslands, beaches, dunes, and sands (Table 4). Since the Canal Istanbul has been in agenda since 2011, an analysis based on the CLC 2012 dataset was also carried out. Compared with the 2018 dataset, there are no significant changes except a decrease in forest areas and increase in construction sites. It is predicted that construction processes are mostly related to NMM that intersects with the Canal Istanbul planning area. It can also be argued that speculations over the construction of the canal have not resulted in significant change in spatial use between 2012 and 2018 .

The CLC map of the planning area is given in Figure 6, which depicts the number of agricultural zones to be removed due to spatial change.

On the other hand, as can be seen in Table 5, the vast majority of the proposed plan consists of residential zones. According to the calculations, more than almost $56 \%$ of the agricultural zones 


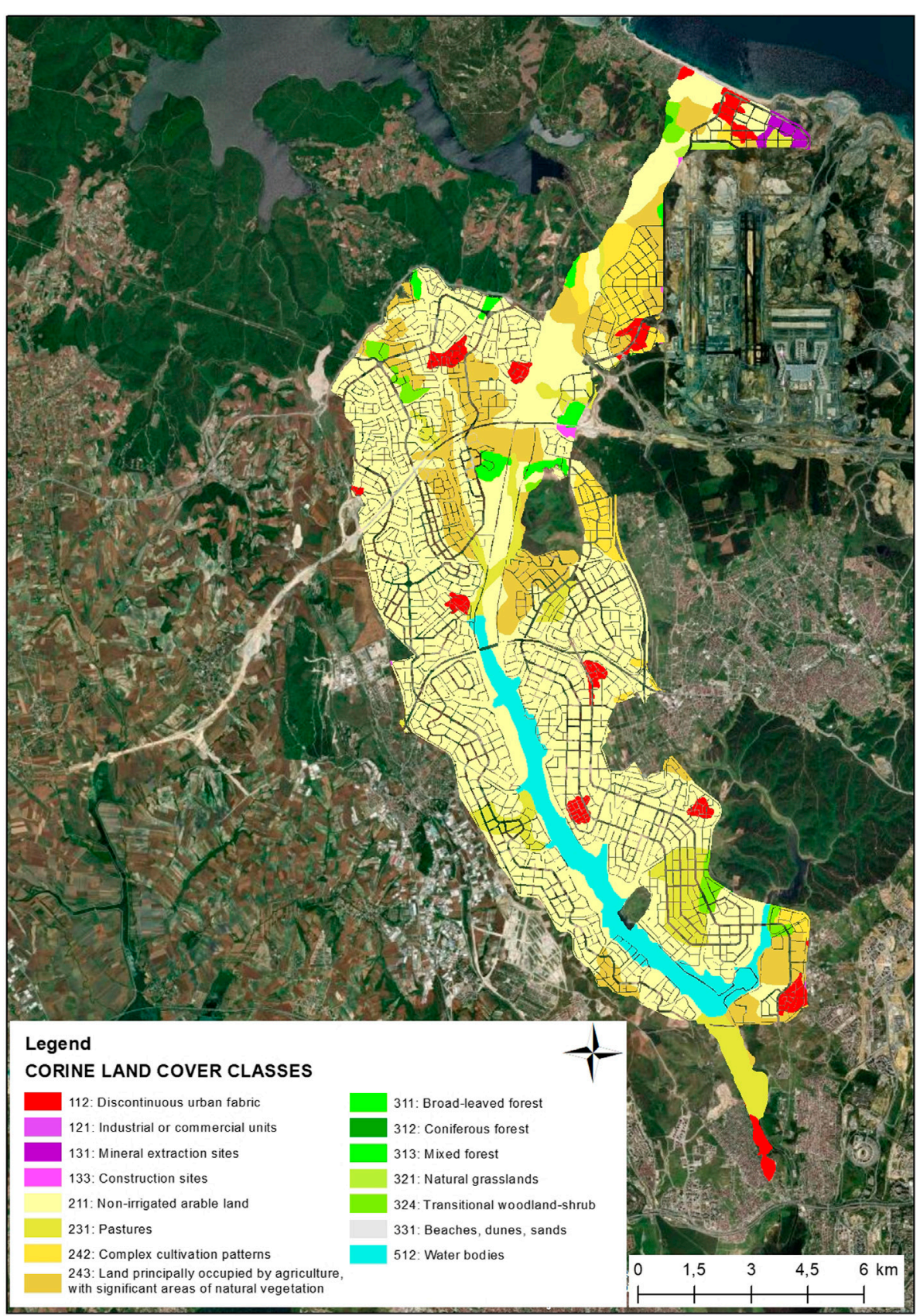

FIGURE 6 | Land cover of Canal Istanbul's plan.

will return into residential areas. Residential areas (low-density, mid-density, and commercial-residential areas) cover almost $44 \%$ of the whole Canal Istanbul's planning zone. Combined with other types of spatial uses such as commercial, educational, logistic, and other artificial land covers, $80 \%$ of the planning area is assigned to spatial use types that will cause a significant change from current use types. Since the "water body" mentioned in the plan is the canal itself, it is also regarded as artificial surface based on the fact that the canal will mainly serve for ship transportation. As a result, only $3.61 \%$ of the planning area is designed as forest and $19.50 \%$ for recreational areas. When considered that recreational areas are also a part of urbanized areas, it can be claimed that current spatial use types in the area with agricultural and ecological value will basically transform into urbanized, artificial forms.

In order to understand the shift from one spatial use type to another that may occur due to Canal Istanbul's spatial plan, the plan and CLC 2018 were compared in the GIS environment. For 
TABLE 5 | Spatial use types as given in Canal Istanbul's spatial plan.

\begin{tabular}{|c|c|c|c|}
\hline Spatial use type & CLC taxonomy equivalent & Area (ha) & Ratio (\%) \\
\hline Low-density residential area & Discontinuous urban fabric & 2905.38 & 26.12 \\
\hline Park and recreation area & Green urban areas & 2169.35 & 19.50 \\
\hline Water body & Water body & 1462.98 & 13.15 \\
\hline Commercial-residential area & Continuous urban fabric & 1061.95 & 9.55 \\
\hline Mid-density residential area & Continuous urban fabric & 868.76 & 7.81 \\
\hline Forest area & Mixed forest & 401.58 & 3.61 \\
\hline Commercial area & Industrial or commercial units & 330.49 & 2.97 \\
\hline Education area & Discontinuous urban fabric & 323.89 & 2.91 \\
\hline Technology development zone & Industrial or commercial units & 223.20 & 2.01 \\
\hline Logistic facility area & Industrial or commercial units & 203.64 & 1.83 \\
\hline Highway protection zone & Road and rail networks and associated land & 150.83 & 1.36 \\
\hline Fair area & Industrial or commercial units & 140.79 & 1.27 \\
\hline Commercial-tourism area & Industrial or commercial units & 137.79 & 1.24 \\
\hline Special project area & Continuous urban fabric & 115.79 & 1.04 \\
\hline Railway protection zone & Road and rail networks and associated land & 75.83 & 0.68 \\
\hline Health facility area & Sport and leisure facilities & 74.28 & 0.67 \\
\hline Technical infrastructure area & Industrial or commercial units & 72.49 & 0.65 \\
\hline Public service area & Discontinuous urban fabric & 44.47 & 0.40 \\
\hline Worship area & Sport and leisure facilities & 41.03 & 0.37 \\
\hline University area & Discontinuous urban fabric & 38.47 & 0.35 \\
\hline Afforestation area & Coniferous forest & 37.76 & 0.34 \\
\hline Special health facility area & Discontinuous urban fabric & 35.86 & 0.32 \\
\hline Special education area & Discontinuous urban fabric & 30.14 & 0.27 \\
\hline Social facility area & Sport and leisure facilities & 29.79 & 0.27 \\
\hline Cultural facility area & Sport and leisure facilities & 29.70 & 0.27 \\
\hline Railway protection zone & Road and rail networks and associated land & 25.20 & 0.23 \\
\hline Municipal service area & Discontinuous urban fabric & 24.74 & 0.22 \\
\hline Special social facility area & Sport and leisure facilities & 19.64 & 0.18 \\
\hline Sport facility & Sport and leisure facilities & 16.83 & 0.15 \\
\hline Urban business area & Discontinuous urban fabric & 12.93 & 0.12 \\
\hline Market place & Industrial or commercial units & 10.98 & 0.10 \\
\hline Fuel-oil station area & Industrial or commercial units & 6.93 & 0.06 \\
\hline
\end{tabular}

the comparison, each spatial use type offered by the plan was matched with CLC taxonomy to make a consistent calculation. CLC 2018 taxonomy equivalent of the spatial use types is given in Table 5. According to the analysis, it is seen that the biggest change is predicted to be in agricultural lands that will convert into continuous and discontinuous urban fabric mostly. A detailed table on the spatial change is given in Supplementary Appendix A4, and a summary graph is presented in Figure 7 for more elaborate information.

By means of ES potential, in relation to the agricultural loss, agriculture-related services are predicted to decrease in the most significant way. In addition to agricultural areas, the current Sazlidere dam that acts as a lagoon in the area will also be lost. Another critical loss will be the pastures that serve as an integral tool for livestock activities. In this regard, especially provisioning services such as crop, livestock, fishing, water culture, and fresh water will be affected (Table 6).

Analysis results show that the loss of the Sazlidere dam and agricultural assets will drop the total ES potential of the area to one-third. It must also be kept in mind that possible diverse impacts of the canal's waterway itself have not been considered within this analysis. In this regard, it can be mentioned that the canal and its plan will not only diminish current ES quality of the area, it may even worsen the services that are provided by the spatial plan of the canal. Therefore, it is predicted that the ecological form in the region is subject to worsen gradually through years.

\section{DISCUSSION}

Although cities are the driver of many unsustainable development trajectories, they are the settlements where the solutions to these problems are accommodated sooner or later. In the Istanbul case here, we aimed to emphasize the significance of "still surviving" pristine ecosystems, rich biodiversity abundance, and their role for ecosystem services potential. Existing and future scenarios are also taken into account to compare the results on ES provision. In this regard, we wanted to highlight how the ES concept can be utilized in the spatial planning, development, and/or decision-making process by using a specific technique called the "matrix model" in the ES literature. The outputs of the study indicate that the methodology can be efficiently used to evaluate and interpret how an investment or a plan can impact ES capacity on a given area. The proposed methodology is also valuable by means of enabling the end-user to grasp a holistic view about the end-results of a plan or project.

Compared with conventional environmental impact assessment methods, especially as implemented in Turkey, 


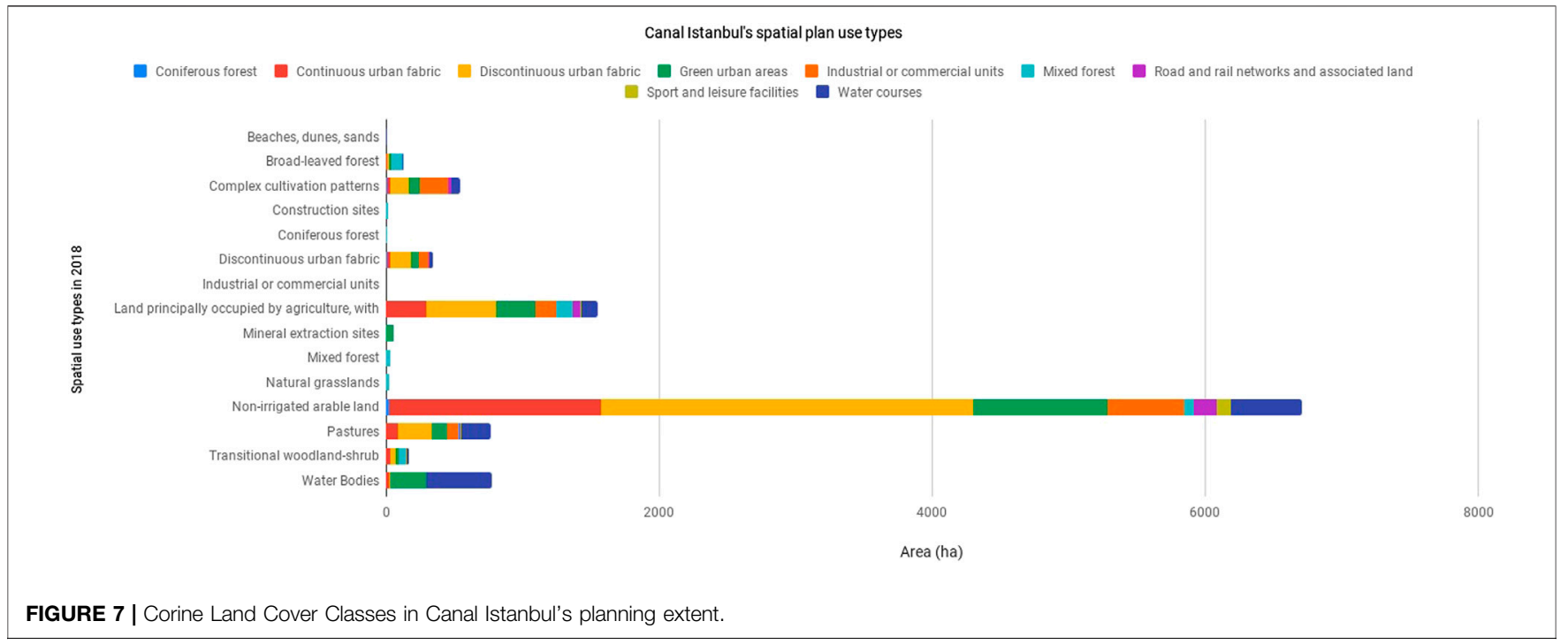

adaptation of the ES concept has significant advantages. The first is that in the current environmental impact assessment process, it is hard to find an analytical result regarding the impact of a case, meaning that, although evaluations are mostly data driven, results are quite qualitative. This may result in a misunderstanding of the comments or synthesis that emerges through the impact assessment reports. Therefore, in controversial studies such as NMM, there may occur speculative discussions on the impact

TABLE 6 | ES potential estimations of Canal Istanbul's spatial plan and CLC 2018

\section{Spatial plan's ES potentia}

Spatial use types

Low-density residential area

Park and recreation area

Forest area

Commercial-residential area

Mid-density residential area

Education area

Afforestation area

Special project area

Health facility area

Public service area

University area

Special health facility area

Special education area

Worship area

Municipal service area

Social facility area

Cultural facility area

Urban business area

Special social facility area

Sport facility

Commercial area

Technology development zone

Logistic facility area

Highway zone

Fair area

Commercial-tourism area

Railway zone

Technical infrastructure area

Railway zone

Market place

Fuel-oil station area

Water body

Total
69729,12

49895,05

35740,62

23362,90

19112,72

7773.32

3284.78

2778.95

1114.20

978.34

923.28

860.61

723.47

615.45

593.79

446.85

445.50

310.20

294.65

252.45

0.00

0.00

0.00

0.00

0.00

0.00

0.00

0.00

0.00

0.00

0.00

0.00

$219.236,26$

\section{CLC 2018 ES potential}

Spatial use types

Water bodies

Total ES potential

53335,50

10292,31

39307,42

Pastures

Nonirrigated arable land

Natural grasslands

Mixed forest

Mineral extraction sites

Land principally occupied by agriculture, with significant areas of natural vegetation

Industrial or commercial units

Discontinuous urban fabric

$362,150,86$

1329.10

2584.87

0.00

75986,66

0.00

8268.60

0.00

365.35

24083,09

11091,30

177.77

$588.972,84$ 
assessment reports. Establishing an analytical approach in environmental impact analysis studies can easily suppress the misguided discussions. Second, current environmental impact assessments rely on situational changes instead of functional or processual changes. For example, the impact analyses mostly focus on the amount of change; nevertheless, from an ecological aspect, the interaction between different components of the environment must also be incorporated, and in addition to their static value/quantity, their functions and potential benefits to humanity and other living organisms must also be taken into account. Therefore, putting the ES concept in the center of the environmental impact assessment process can reduce the qualitative uncertainties and provide integrity to the estimations. It is seen that the EIA process may vary based on the type of the project, concept, and implementation area. Since EIA reports are generated based on strict regulations, their context may reach reasonable volumes, which makes it hard to grasp an overall understanding about the actual impacts. The matrix model, on the other hand, provides a systematic, analytical, and efficient approach not only by means of its applicability but also by means of its detailed insight on the ecological impacts.

Regarding Istanbul's urbanization speed and patterns in the past, it can be predicted that the aforementioned major infrastructures will not only cause habitat loss but also bring new urban forms to the area which will put extra loads on the carrying capacity of the limited natural resources. Combined with the effect of climate change, cascading effects of these investments will possibly worsen sustainability and resilience of Istanbul's ecosystems in the near future.

\section{REFERENCES}

AECOM (2013). Environmental and social impact assessment report for North Marmara motorway including $3^{\text {rd }}$ bridge, Los Angeles, CA: AECOM.

Albayrak, İ. (2012). "Ekosistem Servislerine Dayali Havza Yönetim Modelinin İstanbul-Ömerli Havzasi Örneğinde Uygulanabilirliği [Istanbul Technical University]," in İstanbul Teknik Üniversitesi Fen Bilimleri Enstitüsü, (Yayimlanmamiş Doktora Tezi). Available at: https://dspace.ups.edu.ec/ bitstream/123456789/5224/1/UPS-QT03885.pdf

Alberti, M. (1996). Measuring urban sustainability. Environ. Impact Assess. Rev. 16 (4-6), 381-424. doi:10.1016/s0195-9255(96)00083-2

Arrow, K., Bolin, B., Costanza, R., Dasgupta, P., Folke, C., Holling, C. S., et al. (1995). Economic growth, carrying capacity, and the environment. Science 268, 520-521. doi:10.1126/science.268.5210.520

Avcı, M. (2014). "Kentsel biyolojik çeşitlilik açısından i?stanbul," in İstanbul ormanlarının sorunları ve çözüm önerileri, İstanbul, Turkey, 5-6 Aralık 2013. İstanbul, Turkey. Türkiye Ormancılar Derneği Yayını Marmara Şubesi. 87-124.

Ayazlı, I. E., Batuk, F., and Kleinschmit, B. (2010). "Simulating landuse changes driven by a 3rd bosphorus bridge," in International Archives of the Photogrammetry, Remote Sensing and Spatial Information Sciences- ISPRS Archives, 38.

Balkenhol, N., and Waits, L. P. (2009). Molecular road ecology: exploring the potential of genetics for investigating transportation impacts on wildlife. Mol. Ecol. 18 (20), 4151-4164. doi:10.1111/j.1365-294X.2009.04322.x

Barthelmess, E. L., and Brooks, M. S. (2010). The influence of body-size and diet on road-kill trends in mammals. Biodivers. Conserv. 19 (6), 1611-1629. doi:10. 1007/s10531-010-9791-3
Nevertheless, there may still be room for development and optimism if the current level of ecological functions is preserved and sustained. Even though Istanbul's urban development has not been in favor of the ecological assets, Istanbul is still invaluable by means of its ecosystems, biodiversity, and environment. Therefore, methodologies and approaches as in this study must be enlightening the road of development for Istanbul and allow decision makers make the right call for a more sustainable and resilient city.

\section{DATA AVAILABILITY STATEMENT}

The original contributions presented in the study are included in the article/Supplementary Material. Further inquiries can be directed to the corresponding author.

\section{AUTHOR CONTRIBUTIONS}

The analysis was done and maps were created by EM. Interpretation and writings were carried out equally by EM and AT.

\section{SUPPLEMENTARY MATERIAL}

The Supplementary Material for this article can be found online at: https:/www.frontiersin.org/articles/10.3389/fenvs.2021.614752/ full\#supplementary-material

Bennett, V. J., Smith, W. P., and Betts, M. G. (2011). Toward understanding the ecological impact of transportation corridors. Gen. Tech. Rep. PNW-GTR-846. Portland, OR: U.S. Department of Agriculture, Forest Service, Pacific Northwest Research Station, 40. doi:10.2737/PNW-GTR-846

Biro, E., Bouwma, I., and Grobelnik, V. (2006). Indicative map of the Pan European ecological network in South-eastern Europe. Technical background document. ECNC Technical Report series. Tilburg, Netherlands: ECNC European centre for nature conservation.

Burkhard, B., Kandziora, M., Hou, Y., and Müller, F. (2014). Ecosystem service potentials, flows and demands-concepts for spatial localisation, indication and quantification. Landscape Online 34, 1-32. doi:10.3097/lo.201434

Burkhard, B., Kroll, F., Müller, F., and Windhorst, W. (2009). Landscapes' capacities to provide ecosystem services-a concept for land-cover based assessments. Landscape Online 15, 1-22. doi:10.3097/lo.200915

Cain, A. T., Tuovila, V. R., Hewitt, D. G., and Tewes, M. E. (2003). Effects of a highway and mitigation projects on bobcats in Southern Texas. Biol. Conservation 114 (2), 189-197. doi:10.1016/s0006-3207(03)00023-5

Chen, J., Sun, B. M., Chen, D., Wu, X., Guo, L. Z., and Wang, G. (2014). Land use changes and their effects on the value of ecosystem services in the small Sanjiang plain in China. Sci. World J. 2014, 752846. doi:10.1155/2014/752846

Çinar Mühendislik Müșavirlik A.Ș. (2017). Environmental impact assessment report of Canal Istanbul Project.

Costanza, R., d'Arge, R., de Groot, R., Farber, S., Grasso, M., Hannon, B., et al. (1997). The value of the world's ecosystem services and natural capital. Nature 387, 253-260. doi:10.1038/387253a0

Elmqvist, T., Redman, C. E., Barthel, S., and Costanza, R. (2013). "History of urbanization and the missing ecology," in Urbanization, biodiversity and ecosystem services: challenges and opportunities (13-30). Editors T. Elmqvist, 
M. Fragkias, J. Goodness, B. Güneralp, P. J. Marcotullio, R. I. McDonald, et al. (Amsterdam, Netherlands: Springer). doi:10.1007/978-94-007-7088-1_2

Encon (2018). Environmental impact assessment reports (for asian and European sides) for North Marmara motorway. Istanbul, Turkey.

European Commission (2008). Directive 2008/50/EC of the European parliament and of the council of 21 may 2008 on ambient air quality and cleaner air for Europe. Available at: https://eur-lex.europa.eu/legal-content/EN/TXT/PDF/? uri=CELEX:02008L0050-20150918\&from=EN (Accessed 21 May, 2008).

European Environment Agency (EEA) (2017). Copernicus land service, panEuropean component, corine land cover factsheet.

Food and Agriculture Organization (FAO) (2018). The state of the world's forests 2018. Available at: http://www.fao.org/3/ca0188en/ca0188en.pdf

Forman, R. T. T., and Alexander, L. E. (1998). Roads and their major ecological effects. Annu. Rev. Ecol. Syst. 29 (1), 207-231. doi:10.1146/annurev.ecolsys.29. 1.207

Geneletti, D., Bagli, S., Napolitano, P., and Pistocchi, A. (2007). Spatial decision support for strategic environmental assessment of land use plans. A case study in southern Italy. Environ. Impact Assess. Rev. 27 (5), 408-423. doi:10.1016/j. eiar.2007.02.005

Geneletti, D. (2013). Sustainability assessment. Pluralism, practice and progress. Impact Assess. Project Appraisal 31 (3), 238-239. doi:10.1080/14615517.2013. 779797

Güneralp, B., Tezer, A., and Albayrak, İ. (2013). "Local assessment of Istanbul: biodiversity and ecosystem services," in Urbanization, biodiversity and ecosystem services: challenges and opportunities: a global assessment. Editors T. Elmqvist, M. Fragkias, J. Goodness, B. Güneralp, P. J. Marcotullio, R. I. McDonald, et al. (Dordrecht, Netherlands: Springer Netherlands), 291-311. doi:10.1007/978-94-007-7088-1_16

Guterres, A. (2019). Message on the international day of biological diversity.

Haase, D., Piorr, A., Schwarz, N., and Zasada, I. (2010). "A new tool for integrated and interactive sustainability impact assessment of urban land use changes: The PLUREL iIAT," in Modelling for Environment's Sake: Proceedings of the 5th Biennial Conference of the International Environmental Modelling and Software Society, iEMSs 2010, Ottawa, Canada, July 5-8, 2010. Editors D. A. Swayne, W. Yang, A. A. Voinov, A. Rizzoli, and T. Filatova, Vol. 2, pp. $1265-1272$.

Istanbul Metropolitan Municipality (2017). Environmental master plan progress report, (Unpublished report). Istanbul, Turkey.

Jacobs, S., Burkhard, B., Van Daele, T., Staes, J., and Schneiders, A. (2015). 'The Matrix Reloaded': a review of expert knowledge use for mapping ecosystem services. Ecol. Model 295, 21-30. doi:10.1016/j.ecolmodel.2014. 08.024

Kopperoinen, L., Itkonen, P., and Niemelä, J. (2014). Using expert knowledge in combining green infrastructure and ecosystem services in land use planning: an insight into a new place-based methodology. Landscape Ecol. 29 (8), 1361-1375. doi:10.1007/s10980-014-0014-2

Kışlalıŏglu, M., and Berkes, F. (2010). Çevre ve Ekoloji. Istanbul, Turkey: Remzi Kitabevi.

McPhearson, T., Karki, M., Herzog, C., Santiago Fink, H., Abbadie, L., Kremer, P., et al. (2018). "Urban ecosystems and biodiversity," in Climate change and cities: second assessment report of the urban climate change research network. Editors C. Rosenzweig, W. Solecki, P. Romero-Lankao, S. Mehrotra, S. Dhakal, and S. Ali Ibrahim (New York, NY: New York: Cambridge University Press), 257-318.

Menteșe, E. Y. (2020). Modelling the relation between environmental sustainability and land use plans using GIS techniques. $\mathrm{PhD}$ dissertation. Istanbul, Turkey: Istanbul Technical University.

Millennium Ecosystem Assessment (2005). Ecosystems and human wellbeing: synthesis. Washington DC: Island Press.
Müller, F., Burkhard, B., Hou, Y., Kruse, M., Ma, L., and Wangai, P. (2016). "Indicators for ecosystem services," in Routledge handbook of ecosystem services. Editors P. Potschin, R. Haines-Young, R. Fish, and R. K. Turner (London, United Kingdom: Routlegde), 157-170.

Orishimo, I. (1982). Urbanization and environmental quality. Boston; The Hague; London: Kluwer-Nijhoff Publishing.

Strasburg, J. L. (2006). Conservation biology: roads and genetic connectivity. Nature 440, 875-876. doi:10.1038/440875a

TEEB (2009). The economics of ecosystems and biodiversity for national and international policy makers - summary: responding to the value of nature. Wesseling, Germany.

Terzi, F., Tezer, A., Turkay, Z., Uzun, O., Köylü, P., Karacor, E., et al. (2019). An ecosystem services-based approach for decision-making in urban planning. J. Environ. Plann. Management 63 (3), 433-452. doi:10.1080/09640568.2019.1591355

Tezer, A. (2020). "Istanbul Canal project with sustainable spatial planning perspective," in Kanal Istanbul: a multi-disciplinary scientific evaluation (in Turkish). Editors D. Orhon, S. Sözen, and N. Görür (Istanbul, Turkey: Kultur A.S..), $449-475$

Tezer, A., Turkay, Z., Uzun, O., Terzi, F., Köylü, P., Karacor, E., et al. (2018). Ecosystem services-based multi-criteria assessment for ecologically sensitive watershed management. Environ., Dev. Sustain. 22, 2431-2450. doi:10.1007/ s10668-018-00300-5

Tolunay, D. (2015). “TÜRKIYE'DE ORMANSIZLAŞMA İLE KAYBEDILEN KARBON MIKTARLARI," in 6th National Weather Pollution and Control Symposium, 441-452.

UN (2015). HABITAT III issue papers, 16. New York, NY: Urban Ecosystems and Resource Management

UN (2012). Sustainable land use for the 21st century. Available at: https:// sustainabledevelopment.un.org/content/documents/1124landuse.pdf.

UN-HABITAT (2002). Sustainable urbanisation. Geneve, Switzerland: UNHABITAT.

United Nation (2004). "World Population Prospects The 2004 Revision," in Population (English Edition), Vol. 3. Available at: https://www.un.org/ development/desa/pd/sites/www.un.org.development.desa.pd/files/files/documents/ 2020/Jan/un_2004_world_population_prospects-2004_revision_volume-iii.pdf

Url-1. Available at: http://www.kuzeymarmaraotoyolu.com/en/about-the-project; AVRUPA OTOYOLU YATIRIM VE ISSLETME A.Ş. and European side and KMO ANADOLU OTOYOLU İSLETME A.Ș. (Accessed October 1, 2020).

Url-2. Available at: https://dhmi.gov.tr/Sayfalar/Havalimani/Istanbul/GenelBilgiler. aspx; "General Directorate Of State Airports Authority" (Accessed October 1, 2020).

Vega-Azamar, R., Romero-López, R., Glaus, M., Oropeza-García, N., and Hausler, R. (2015). Sustainability assessment of the residential land use in seven boroughs of the island of montreal, Canada. Sustainability 7 (3), 2454-2472. doi:10.3390/su7032454

Westman, W. E. (1977). How much are nature's services worth? Science 197 (4307), 960-964. doi:10.1126/science.197.4307.960

Conflict of Interest: The authors declare that the research was conducted in the absence of any commercial or financial relationships that could be construed as a potential conflict of interest.

Copyright $\odot 2021$ Mentese and Tezer. This is an open-access article distributed under the terms of the Creative Commons Attribution License (CC BY). The use, distribution or reproduction in other forums is permitted, provided the original author(s) and the copyright owner(s) are credited and that the original publication in this journal is cited, in accordance with accepted academic practice. No use, distribution or reproduction is permitted which does not comply with these terms. 